\title{
HUBUNGAN IKLAN POLITIK KANDIDAT PRESIDEN TERHADAP TINGKAT KOGNISI DAN SIKAP POLITIK PEMILIH PEMULA
}

\author{
Ansar Suherman \\ Program Studi Ilmu Pemerintahan, Fakultas Ilmu Sosial dan Ilmu Politik, \\ Universitas Muhammadiyah Buton, Jl. Betoambari No. 36 Baubau. \\ E-mail:ansar.suherman@yahoo.co.id
}

\begin{abstract}
Abstrak
Penelitian ini bertujuan untuk mengetahui hubungan iklan politik dengan tingkat kognisi dan sikap politik pemilih pemula. Metode yang digunakan adalah metode deskriptif korelasional melalui pendekatan kuantitatif. Penelitian ini berlokasi di kota Baubau, provinsi Sulawesi Tenggara dengan jumlah sampel 377 responden yang kesemuanya merupakan pemilih pemula. Untuk mengumpulkan data yang diperlukan, digunakan kuesioner yang disebarkan kepada seluruh responden. Beberapa uji statistik yang digunakan adalah uji syarat statistik dan uji hipotesis Iklan politik yang dijadikan subyek penelitian ini adalah iklan politik Abu Rizal Bakrie, Prabowo Subianto, dan Wiranto. Hasil penelitian menunjukkan bahwa iklan politik di televisi lebih efektif dalam menyampaikan pesan kepada responden karena televisi mampu memberikan tampilan audio dan visual secara bersama-sama. Iklan politiknya juga memberikan sumbangan yang efektif terhadap peningkatan kognisi dan sikap politik responden. Responden merasakan manfaat dari iklan politik karena responden umumnya mendapatkan pengetahuan tentang visi dan misi kandidat. Terlihat perubahan sikap responden yang merupakan akumulasi dari informasi dan tingkat kognisi atau pengetahuan yang diperoleh responden dari iklan politik yang ditonton. Semakin tinggi tingkat kognisi responden terhadap kandidat presiden maka akan semakin memengaruhi sikap politik responden. Dalam penelitian ini juga ditemukan bahwa faktor lingkungan (dukungan politik orang tua dan sikap politik lingkungan sekitar) ikut memengaruhi tingkat kognisi dan sikap politik responden
\end{abstract}

Kata kunci: iklan politik, kognisi, sikap politik, pemilih pemula.

\begin{abstract}
This study aims to determine the relationship of political advertising with the level of cognition and political attitudes voters. The method used is the method quantitative descriptive correlational approach. This study is located in Southeast Sulawesi Baubau City with a sample of 377 respondents of whom are first-time voters. To collect the necessary data, used questionnaires distributed to all respondents. Some of the statistical test used is the statistical terms and tests the hypothesis that political ads are used as research subjects Abu Rizal Bakrie political advertising, Prabowo and Wiranto. The results showed that political advertising on television is more effective in conveying the message to the respondent because the television is able to provide audio and visual display together. Political ad also contribute effectively to the improvement of cognition and political attitudes of the respondents. Respondents felt the benefit of political advertising because respondents generally gain knowledge of the candidate's vision and mission. Visible changes in the attitude of the respondents which is the accumulation of information and the level of cognition or knowledge gained from the respondents who watch political ads. The higher level of cognition of respondents to the presidential candidates will increasingly affect the political attitudes of the respondents. In this study also found that environmental factors (political support parents and attitudes about environmental politics) did influence the level of cognition and political attitudes of the respondents.
\end{abstract}

Keywords: political advertising, cognition, political attitudes, youth voters. 


\section{SANG PENCERAH}

Volume 2, Nomor 1, Februari 2016, Hlm. 1-7

Ansar Suherman: Hubungan Iklan Politik Kandidat Presiden ...

\section{Pendahuluan}

Taktik memperkenalkan diri di hadapan pemilih utamanya pemilih pemula yang menjadi sumber suara yang cukup besar adalah melalui media massa seperti televisi, surat kabar, dan internet. Daya jangkau dan tingkat penertasi beriklan di media massa tersebut jauh lebih baik dibandingkan dengan menyebarkan brosur, stiker, spanduk, baliho, dan sejenisnya. Terlebih jika hal tersebut dilakukan melalui media televisi. Cangara (2011) menyebutkan bahwa iklan sebagai sebuah bentuk pembayaran yang dilakukan untuk membeli tempat atau ruang dalam menyampaikan pesan-pesan lembaga atau institusi dalam media. Menurut Jefkins (2009), televisi meskipun tergolong sebagai media konvensional akan tetapi, efek yang ditimbulkan jauh lebih besar, bahkan hingga kini televisi tidak tergantikan efektifitasnya untuk mengerahkan persepsi publik. Danial (2009) menyebutkan media konvensional seperti Media televisi dapat membentuk kepercayaan (trust) terhadap publik. Oleh karena itu, iklan politik (political ads) di televisi memang sudah seharusnya menjadi sebuah keperluan dalam memperkenalkan kandidat calon presiden (capres) untuk memperoleh aksetabilitas, dan elektabilitas dalam Pemilihan Umum Presiden (Pilpres) nanti.

Berkaitan dengan penelitian tentang iklan, salah satu teori yang dapat digunakan sebagai pijakan dalam melihat konsepsi periklanan adalah Selective Influence Theory atau teori terpaan selektif oleh Klapper yang menjelaskan bagaimana khalayak merespon pesan-pesan iklan dari media massa dapat diterangkan melalui teori selective influence ini yang terdiri dari empat prinsip yaitu selective attention, selective perception, selective recall, dan selective action. (Liliweri (2011).

Terkait dengan jumlah wajib pilih untuk Pemilu 2014, KPU Pusat merilis data keseluruhan wajib pemilih seluruh Indonesia sebanyak 181.139.037 wajib pilih,
$30 \%-40 \%$ nya adalah pemilih pemula (Kompas, 2014). Berdasarkan UndangUndang Pemilihan Umum, yang dikategorikan sebagai pemilih pemula adalah mereka yang telah berusia 17-21 tahun, telah memiliki hak suara dan tercantum dalam Daftar Pemilih Tetap (selanjutnya disingkat DPT). Angka 30\% yang merupakan persentase dari jumlah pemilih pemula akan sangat menentukan kemenangan pasangan capres dan cawapres dalam Pilpres 2014 mendatang. Sehingga tidak mengherankan jika potensi pemanfaatan basis pemilih pemula menjadi salah satu sasaran dari iklan politik para kandidat capres. Selain secara statistik, signifikansi pemilih pemula juga terletak pada karakteristik pemuda yang berbeda bila dibandingkan dengan segmentasi pemilih yang lain. Menurut Muhtadi (2013), pemilih pemula secara umum terbagi menjadi dua. Pertama, kelompok apatis atau apolitis. Kelompok ini biasanya teralienasi dari sistem atau proses politik yang ada. Oleh karena itu, pemuda ini mudah terseret ke dalam arus golongan putih (selanjutnya disingkat golput) karena pemilu dianggap tidak terkait dengan kepentingan pragmatis mereka. Kedua, kelompok pemuda yang rasional atau kritis. Karakteristik pemuda yang rasional atau kritis bisa berujung pada dua hal: golput atau memilih, tetapi "mudah pindah ke lain hati".

Pemilihan kota Baubau sebagai lokasi penelitian dikarenakan struktur kehidupan masyarakat di kota ini sangat heterogen, baik dari segi sosial, ekonomi, politik, agama, dan kebudayaan, menjadikan kota Baubau sebagai daerah yang sangat dinamis dalam pola kehidupan sosial dan politiknya. Selain itu, Baubau memiliki jumlah wajib pilih terbesar kedua di Provinsi Sulawesi Tenggara.

Hasil-hasil penelitian yang sejenis diantaranya, penelitian Valentino (2004) yang melakukan pengukuran terhadap dampak iklan politik terhadap pengetahuan, 


\section{SANG PENCERAH}

Volume 2, Nomor 1, Februari 2016, Hlm. 1-7

Ansar Suherman: Hubungan Iklan Politik Kandidat Presiden ...

pencarian informasi dari internet, dan preferensi calon presiden. Penelitian itu menghasilkan kesimpulan bahwa dalam bentuk efek informasi yang sifatnya langsung dan sederhana, iklan politik memberi keuntungan bagi warga negara, khususnya ketika ketersediaan informasi sangat kurang; dan penelitian yang dilakukan oleh Alfisyahr dengan judul Analisa pengaruh iklan calon presiden terhadap pembentukan brand attitude dan intention to vote: studi komparasi berdasarkan iklan politik Prabowo Subianto dan Rizal Mallarangeng.

Tujuan umum dari penelitian ini adalah untuk mengukur hubungan antara tingkat kognisi dan sikap politik pemilih pemula terhadap iklan politik kandidat presiden Republik Indonesia tahun 2014 di media massa dengan menelaah seluruh iklan politik melalui media massa khususnya televisi.

\section{Metode Penelitian}

\section{Lokasi dan Desain Penelitian}

Penelitian ini berlokasi di Kota Baubau Propinsi Sulawesi Tenggara dan waktu pelaksanaan penelitian selama kurang lebih 4 bulan. Desain dalam penelitian ini, peneliti menggunakan jenis penelitian deskriptif korelasional melalui pendekatan kuantitatif yang bertujuan untuk mengetahui keeratan hubungan antar variabel-variabel yang diteliti (Arikunto, 2009). Peneliti menggunakan metode ini untuk mengetahui hubungan antara iklan politik kandidat presiden dengan tingkat kognisi dan sikap politik pemilih pemula.

\section{Populasi dan Sampel}

Populasi dalam penelitian ini adalah seluruh pemilih pemula tahun 2014 yang sudah masuk DPT di Kota Baubau. Populasi dalam penelitian ini adalah populasi heterogen. Teknik sampling dilakukan dengan cara sebagai berikut: pertama, memilih sampel wilayah secara purpossive sampling, yaitu memilih beberapa wilayah kecamatan dari 8 kecamatan yang ada di kota Baubau yang masing-masing mewakili daerah pinggir kota dan pusat kota. Daerah pinggir kota yang dimaksud adalah daerah yang letaknya berada dibagian ujung atau perbatasan kota Baubau dengan daerah lainnya, sedangkan daerah pusat kota adalah ibukota Baubau; Kedua, untuk penentuan sampel respondennya menggunakan cluster sampling dengan kriteria respondennya adalah pemilih pemula yang terdaftar sebagai wajib pilih dalam DPT di Komisi Pemilihan Umum (KPU) Kota Baubau, berusia 17 - 21 tahun, memiliki media televisi, pernah menyaksikan iklan politik kandidat capres R.I. tahun 2014 di televisi, yakni iklan politik ARB, Prabowo, dan Wiranto. Berdasarkan rumus yang digunakan, diperoleh jumlah sampel sejumlah 377 responden.

Untuk memperoleh data secara terperinci dan baik, maka peneliti menggunakan beberapa metode, yaitu dengan menggunakan kuesioner dan wawancara. Teknik yang digunakan dalam menganalisis data yang diperoleh dalam penelitian ini menggunakan bantuan program SPSS for Windows vrsi 16. Beberapa uji statistik yang dilakukan adalah (1) uji validitas. Setiap pertanyaan dianggap valid apabila nilai $r_{\text {hitung }}$ pada kolom correlated item total correlation > nilai $\mathrm{r}_{\text {kritis }}$; (2) uji reliabilitas, Asumsi dalam uji reliabilitas ini adalah apabila nilai instrumen penelitian memiliki nilai cronbach's alpha adalah sama dengan atau atau leboh besar dari 0,8 maka dapat dikatakan reliabel; (3) uji normalitas, dimaksudkan untuk memperlihatkan bahwa data sampel berasal dari populasi yang berdistribusi normal. Ada beberapa teknik yang dapat digunakan untuk menguji normalitas data, antara lain dengan kertas peluang normal, uji chi-kuadrat, uji Liliefors, dan Teknik Kolmogorov-Smirnov dengan 


\section{SANG PENCERAH}

Volume 2, Nomor 1, Februari 2016, Hlm. 1-7

Ansar Suherman: Hubungan Iklan Politik Kandidat Presiden ...

SPSS. Untuk penelitian ini, peneliti menggunakan teknik Kolmogorov-Smirnov test untuk menguji kenormalan distribusi dari sampel; (4) uji koefisien korelasi, Uji korelasi dilakukan untuk menguji hipotesis yang telah diajukan dalam penelitian ini; dan (5) uji regresi linear berganda. Analisis regresi digunakan untuk mengetahui pengaruh secara parsial maupun simultan antara variabel bebas (X) Iklan Politik kandidat calon presiden di televisi terhadap variabel terikat Tingkat Kognisi pemilih pemula (Y1), dan variabel Sikap Politik Pemilih Pemula (Y2).

\section{Pembahasan}

Tabel 1. Data Usia Responden

\begin{tabular}{ccc}
\hline Usia & Jumlah & Persentase \\
\hline 17 Tahun & 117 & 31,03 \\
18 Tahun & 88 & 23,34 \\
19 tahun & 63 & 16,71 \\
20 Tahun & 50 & 13,26 \\
21 Tahun & 59 & 15,65 \\
\hline Total & $\mathbf{3 7 7}$ & $\mathbf{1 0 0} \%$
\end{tabular}

Sumber: diolah dari hasil penelitian.

Tabel 1 menunjukkan profil usia responden yang 117 respondennya berada di usia 17 tahun $(31,03 \%), 88$ responden berusia 18 tahun $(23,34 \%), 63$ responden berusia 19 tahun $(16,71 \%), 50$ responden berusia 20 tahun $(13,26 \%)$, dan 59 responden berusia 21 tahun $(15,65 \%)$.

Tabel 2. Frekuensi Menyaksikan Tayangan Iklan Politik Capres Di TV

\begin{tabular}{lcc}
\hline $\begin{array}{c}\text { Jumlah Tayangan } \\
\text { Iklan/Hari }\end{array}$ & Jumlah & \% \\
\hline$>15$ tayangan & 51 & 13,53 \\
10 - 15 tayangan & 203 & 53,85 \\
5 - 10 tayangan & 99 & 26,26 \\
$<5$ tayangan & 24 & 6,37 \\
\hline Total & $\mathbf{3 7 7}$ & $\mathbf{1 0 0} \%$ \\
\hline
\end{tabular}

Sumber: diolah dari hasil penelitian.
Tabel 2 menunjukkan bahwa mayoritas responden memiliki frekuensi menyaksikan iklan politik kandidat presiden antara 10 - 15 iklan/hari atau sejumlah 203 responden $(53,85 \%), 5-10$ tayangan iklan/hari sejumlah 99 responden $(26,26 \%)$, $>15$ tayangan iklan/hari sejumlah 51 responden $(13,53 \%)$, dan 24 responden $(6,37 \%)$ menyaksikan $<5$ tayangan iklan/hari.

Tabel 3. Preferensi Responden tentang Pemilihan Umum

\begin{tabular}{lcc}
\hline \multicolumn{1}{c}{$\begin{array}{c}\text { Partisipasi dalam } \\
\text { Pemilu* }\end{array}$} & Jumlah & $\%$ \\
\hline Sudah Pernah & 43 & 11,41 \\
Belum Pernah & 334 & 88,59 \\
\hline Total & $\mathbf{3 7 7}$ & $\mathbf{1 0 0 \%}$ \\
\hline *Pemilu Kepala daerah & dan & Pemilu \\
$\begin{array}{l}\text { Legislatif/Presiden sebelumnya } \\
\text { Sumber: diolah dari hasil penelitian. }\end{array}$
\end{tabular}

Tabel 3 berisi profil tentang preferensi politik pemilih pemula sebagai responden. Hal ini penting untuk melihat apakah tingkat kognisi dan sikap politik pemilih pemula berkaitan dengan tingkat preferensi politik responden. Berdasarkan tabel ini dapat dilihat bahwa hanya sebagian kecil responden yang sudah pernah mengikuti pemilihan umum. Dari total 377 responden, hanya $43(11,41 \%)$ orang responden yang sudah pernah terdaftar sebagai wajib pilih dan mengikuti Pemilu tersebut, dan sebagian besar atau 334 (88,59\%) orang responden belum pernah mengikuti Pemilu. Pemilu yang diikuti oleh responden yang sudah pernah ikut Pemilu adalah Pemilihan Umum Kepala Daerah (Pemilukada) Kota Baubau yang dilaksanakan pada tahun 2012.

\section{Uji hipotesis}

Hasil analisis uji koefisien korelasi dengan menggunakan program SPSS menunjukkan analisis korelasi linear untuk sampel 337 responden yang menunjukkan korelasi yang positif antar variabel. Hasil pengujian korelasi yang menunjukkan 0,125 


\section{SANG PENCERAH}

Volume 2, Nomor 1, Februari 2016, Hlm. 1-7

\section{Ansar Suherman: Hubungan Iklan Politik Kandidat Presiden ...}

untuk variabel iklan politik (X), 0,98 untuk variabel tingkat kognisi (Y1), dan 1 untuk variabel sikap politik (Y2), menunjukkan hubungan ketiga variabel tersebut sangat kuat. Acuan penentuan hubungan yang kuat mensyaratkan bahwa jika nilai korelasi berada pada 0,80-1 maka korelasi sangat kuat. Salah satu variabel semakin kuat, maka variabel lain semakin besar pula. (Sarwono, 2006).

Tabel 5. Analisis Regresi Variabel Iklan Politik Kandidat Capres (X) Terhadap Variabel Tingkat Kognisi Pemilih Pemula (Y1).

\begin{tabular}{lrrrrrr}
\hline \multirow{2}{*}{ Model } & \multicolumn{2}{c}{$\begin{array}{c}\text { Unstandardized } \\
\text { Coefficients }\end{array}$} & \multicolumn{2}{c}{$\begin{array}{c}\text { Standardized } \\
\text { Coefficients }\end{array}$} & \multicolumn{1}{c}{ t } & Sig. \\
\cline { 2 - 5 } & \multicolumn{1}{c}{ B } & Std. Error & \multicolumn{2}{c}{ Beta } & & \\
\hline (Constant) & 18.585 & 1.376 & & 13.508 & .000 \\
Iklan_- & .054 & .066 & .042 & .813 & .417 \\
Politik & & & & & & \\
\hline
\end{tabular}

a. Dependent Variable:

Tingkat_Kognisi

Sumber: diolah dari hasil penelitian.

Tabel 5 adalah hasil analisis regresi linear Berdasarkan tabel 4.11 di atas, dapat diperoleh persamaan regresi sebagai berikut: $\mathrm{Y} 1=18,585+0,054 \mathrm{X}$. Dari persamaan regresi tersebut, apabila $X$ berubah 1 satuan maka Y1 akan naik sebesar 18,639, dan kedua variabel tersebut ( $X$ dan $Y 1$ ) memiliki saling pengaruh yang signifikan. Dengan kata lain, hubungan yang positif menunjukkan arah yang sama pada hubungan antar variabel semakin besar, sehingga variabel yang lain juga akan semakin besar. Sedangkan untuk hasil regresi antara variabel $\mathrm{X}$ dengan variabel $\mathrm{Y} 2$, diperoleh persamaan regresi sebagai berikut: $\mathrm{Y} 2=16,841+0,220 \mathrm{X}$. Dari persamaan regresi tersebut, apabila $X$ berubah 1 satuan maka Y2 akan naik sebesar 17,061, dan kedua variabel ( $X$ dan $Y 2$ ) tersebut memiliki saling pengaruh yang signifikan. Dengan kata lain, hubungan yang positif menunjukkan arah yang sama pada hubungan antar variabel semakin besar, sehingga variabel yang lain juga akan semakin besar.

Penelitian ini menunjukkan bahwa perbedaan individu ternyata memengaruhi pemahaman mereka atas isi pesan yang disampaikan oleh media. Secara umum, dalam penelitian ini menunjukkan adanya kecenderungan khalayak untuk memilih, menginterpretasi, serta mengingat gambaran yang konsisten dengan atau memantapkan sikap dan keyakinan mereka. Tentang hal tersebut, penting untuk diketahui bahwa khalayak tidak selalu memiliki kontrol atas terpaan iklan terhadap mereka, dan bahwa isi pesan iklan tidak selalu cukup ambigu untuk memberikan berbagai interpretasi ganda atau memori selektif kepada khalayak. Perbedaan responden bisa jadi memiliki peran dalam penguatan beberapa situasi, tetapi di sisi lain mereka dapat menolak atau justru meningkatkan hubungan antara kemampuan iklan politik kandidat capres dalam memberikan sumbangan yang signifikan terhadap tingkat kognisi responden.

Elemen bangunan sikap secara kognitif sejumlah pemilih pemula di kota Baubau tidak hanya dipengaruhi oleh iklan politik kandidat presiden, namun lebih dari itu, juga dimungkinkan akibat kurangnya kandidat presiden yang sebenarnya memiliki potensi dan kemampuan yang lebih baik akan tetapi tidak secara maksimal ditampilkan oleh media massa. Berdasarkan teori selective influence (Liliweri, 2011), dalam penelitian ini khalayak menunjukkan bahwa perbedaan individu ternyata memengaruhi pemahaman mereka atas isi pesan yang disampaikan oleh media. Secara umum, dalam penelitian ini menunjukkan adanya kecenderungan khalayak untuk memilih, menginterpretasi, serta mengingat gambaran yang konsisten dengan atau memantapkan sikap dan keyakinan mereka. Tentang hal tersebut, penting untuk diktahui bahwa khalayak tidak selalu memiliki kontrol atas terpaan iklan terhadap mereka, dan bahwa 


\section{SANG PENCERAH}

Volume 2, Nomor 1, Februari 2016, Hlm. 1-7

\section{Ansar Suherman: Hubungan Iklan Politik Kandidat Presiden ...}

isi pesan iklan tidak selalu cukup ambigu untuk memberikan berbagai interpretasi ganda atau memori selektif kepada khalayak. Perbedaan responden bisa jadi memiliki peran dalam penguatan beberapa situasi, tetapi di sisi lain mereka dapat menolak atau justru meningkatkan hubungan antara kemampuan iklan politik kandidat capres dalam memberikan sumbangan yang signifikan terhadap tingkat kognisi responden.

Temuan kedua yang berkaitan dengan hubungan antara iklan politik dan sikap politik adalah: meskipun ada faktor lain yang membentuk sikap politik responden, aspek iklan politik televisi tetap menjadi prioritas utama dan titik tekan variabel dalam penelitian ini. Bahwa iklan politik yang secara maksimal mampu menampilkan visualisasi yang baik, penyampaian isi pesan yang mudah dipahami, dan penggunaan media yang tepat, akan mampu memengaruhi sikap responden. Oleh teori selective influence yang merupakan suatu teori di bidang ilmu komunikasi yang menyatakan bahwa orang lebih suka terhadap argumen yang mendukung posisinya daripada yang mendukung posisi lainnya. Sebagai konsumen media yang memiliki banyak pilihan untuk menerpa diri mereka terhadap medium terpilih serta konten media yang mereka setujui, mereka cenderung untuk memilih konten yang menkonfirmasi ide-ide mereka dan menolak informasi yang menolak opini mereka. Seseorang tidak ingin dikatakan bahwa mereka salah dan mereka juga tidak ingin ide-ide mereka diubah. Oleh karena itu, mereka memilih saluran media yang berbeda yang menyetujui pendapat dan opini mereka, sehingga mereka tidak harus berhubungan dengan berbagai bentuk disonansi/ketidak cocokan. Lebih jauh lagi, orang-orang tersebut akan memilih sumber media yang mendukung pendapat dan sikap mereka pada subjek-subjek yang berbeda dan selanjutnya mereka akan mengikuti program tersebut. Temuan yang terakhir adalah Berdasarkan hasil analisis data yang telah dilakukan, diketahui bahwa keberadaan iklan politik kandidat presiden memiliki nilai signifikansi dalam meningkatkan level kognitif pemilih pemula dan cukup efektif dalam menggerakkan dan memengaruhi sikap politik pemilih pemula untuk dapat memberikan sikap politik atau dukungannya terhadap kandidat presiden yang beriklan.

Kondisi di atas, menurut hemat penulis didukung oleh keadaan dari tingkat kognisi atau pengetahuan pemilih pemula terhadap aspek-aspek ikllan para kandidat presiden yang cukup aplikatif dan efektif dalam memengaruhi aspek kognitif para pemilih pemula di Kota Baubau. Iklan politik telah mampu menjadi sebagai salah satu sumber referensi atau sumber pengetahuan baru bagi responden yang belum memiliki preferensi politik sebelumnya. Berdasarkan teori integrasi informasi (Sumartono, 2012) bahwa sebuah sikap merupakan sebuah akumulasi dari informasi atau pengetahuan tentang sesuatu, objek, orang, situasi atau pengalaman. Perubahan sikap responden terjadi karena adanya kognisi (pengetahuan) baru yang memberikan tambahan pada sikap mereka. Sikap responden ini mempunyai korelasi dengan keyakinan dan menyebabkan responden memiliki perilaku tertentu terhadap salah satu kandidat capres.

Menurut teori ini, adanya akumulasi informasi dan pengetahuan yang diserap seseorang dapat menyebabkan responden merubah derajat kepercayaannya terhadap suatu objek, dan dapat merubah kredibilitas serta dapat pula menambah kepercayaan baru yang telah ada dalam struktur sikap responden. Seperti halnya oleh teori Hierarchy of effecy model bahwa pada tahap ini terjadi proses awareness dan knowledge. Awareness akan muncul disaat audiens belum mengetahui akan sebuah produk, maka komunikasi bertugas untuk 


\section{SANG PENCERAH}

Volume 2, Nomor 1, Februari 2016, Hlm. 1-7

\section{Ansar Suherman: Hubungan Iklan Politik Kandidat Presiden ...}

menciptakan awareness akan sebuah produk. Selanjutnya pada tahap knowledge (pengetahuan), kesadaran konsumen yang sudah dan berusaha untuk mengambil sebuah tindakan.

\section{Simpulan}

Simpulan penelitian ini bahwa keberadaan iklan politik calon presiden sangat membantu pemilih pemula dalam mengenal figur termasuk visi dan misi kandidat calon presiden. hal tersebut terlihat dari hasil penelitian yang menunjukkan bahwa $190(50,4 \%)$ responden menyatakan sangat setuju dan $172(45,6 \%)$ menyatakan setuju iklan politik membantu mereka dalam mengenal figur capres, sedangkan untuk konstruk sikap politik yang menyatakan bahwa keberadaan iklan politik baik itu frekuensi, durasi, isi pesan, format pesan, sumber pesan, dan visualisasi iklan mampu memberikan pengaruh positif terhadap sikap politik pemilih pemula.

\section{Daftar Pustaka}

Arikunto, S. 2009. Prosedur Penelitian: Suatu Pendekatan Praktek. Jakarta: Rineka Cipta.

Bungin, B. 2013. Metodologi Penelitian Kuantitatif, Edisi Kedua. Jakarta: Kencana Prenada Media Group.

Cangara, H. 2011). Komunikasi Politik; Konsep, Teori, dan Strategi. Edisi Revisi. Jakarta: Rajawali Pers.

Danial, A. 2009. Iklan Politik Televisi: Modernisasi Kampanye Politik Pasca Orde Baru. Jakarta: Grahamedia.
Jefkins, P. \& Olso, J.C. 2009. Periklanan. Edisi 3. Terjemahan oleh Damos Sihombing. Jakarta: Erlangga.

Kompas, 20 Juli 2008. Iklan Politik di Media Massa Lebih Efektif. Edisi, 25 Maret 2008 (online). (http://www.kompas.com, diakses, 20 Februari 2014).

Kriyantono, R. 2012. Teknik Praktis Riset Komunikasi. Jakarta: Kencana Prenada Media Group.

Liliweri, A. 2011. Komunikasi: Serba Ada Serba Makna. Jakarta: Kencana Prenada Media Group.

Muhtadi, B. 2013. Perang Bintang 2014; Konstelasi dan Prediksi Pemilu dan Pilpres. Jakarta: Noura Books.

Sumartono. 2012. Terperangkap dalam Iklan (Meneropong Imbas Pesan Iklan Televisi). Bandung: Alfabeta.

Valentino. 2004. "The Impact of Political Advertising on Knowledge, Internet Information Seeking, and Candidate Preference", Vol. 5 Journal of Communication. 